\title{
Superior Mediastinal Teratoma- A Case Report with review of literature
}

\author{
Elaf Abdulwahhab Hamdi*, Rabea Salim Abd Aljabbar Sofi Ali**, \\ Professor Wahda Mohammad Taib Al-Nuaimy* \\ *Department of Pathology, College of Medicine, University of Mosul, ** Department of Cardiothoracic and \\ Vascular Surgery, Al-Jumhuri Teaching Hospital , Nineveh-Health Office , Mosul, Iraq \\ Correspondence: ela@uomosul.edu.iq
}

(Ann Coll Med Mosul 2021; 43 (1):87-90).

Received: $21^{\text {th }}$ Dece 2020; Accepted: $11^{\text {th }}$ April 2021.

\begin{abstract}
"A teratoma is a germ cell tumor composed of tissue derived from two or three germ layers-ectoderm, mesoderm, and endoderm". Teratomas are mostly found in children \& young adults \& usually originated in gonads \& extragonadal midline tissues such as retroperitoneum, sacrococcygeal region \& mediastinum. Mediastinal teratomas are relatively rare representing $3 \%$ of all tumors within the chest with an average incidence of 8 cases per year and the anterior mediastinum being the most common site for these tumors, benign teratomas form only $10 \%$ of them. We are presenting a case of 39 years old male who presented with progressive exertional dyspnea, orthopnea with frequent attacks of cough for 3years and feeling of pulsatile mass in left upper parasternal area in the last 4 months. Chest $x$-ray showed superior mediastinal shadow projecting to left upper chest zone and deviating the trachea to the right side of chest, provisional diagnosis was aneurysm of aortic arch. Computed tomography (CT) scan of chest and CT angiography done and revealed a superior mediastinal mass of heterogeneous opacity containing fluid, soft tissue, bones and calcification encroaching the right pulmonary artery and compressing and deviating the trachea to the right. Complete surgical removal done through left thoracotomy, Final diagnosis of a mature cystic teratoma was given on histopathology. This case is being presented here because mediastinum is a rare site for teratoma and superior mediastinal teratoma was reported in only few cases from review of literature.
\end{abstract}

Keywords: teratoma , germ cell tumor , mediastinum , Superior mediastinal Teratoma .

$$
\begin{aligned}
& \text { ورم المنصف الصدري العلوي المسخي : تشجيل حالة مع مراجعة مقال }
\end{aligned}
$$

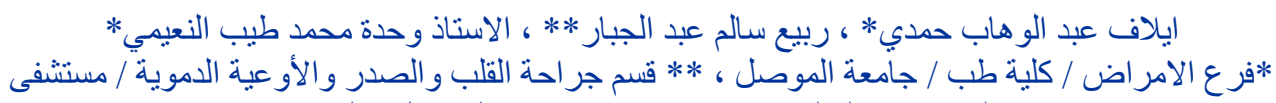

$$
\begin{aligned}
& \text { الجمهوري التعليمي / دائرة صحة نينوى / الموصل / العر اق القاوعا }
\end{aligned}
$$

الورم المسخى هو ورم الخلية الجرثومية ويتكون من نسيج مشتق من طبقتين أو ثلاث طبقات جرثومية ـ الأديم الظاهر، و والأديم

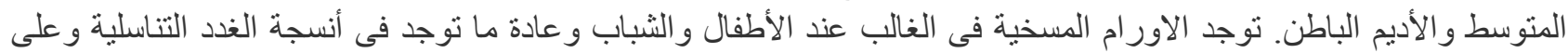

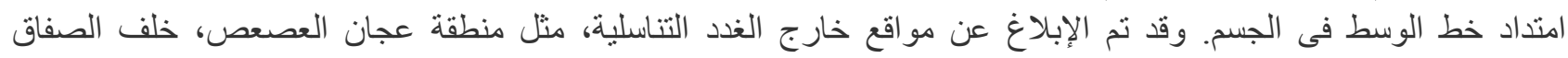

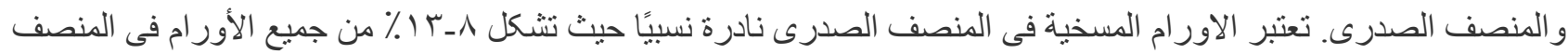

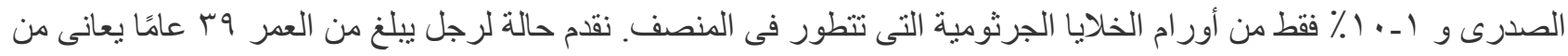

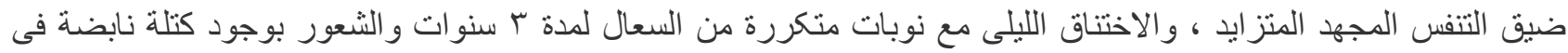

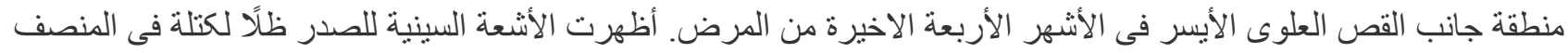

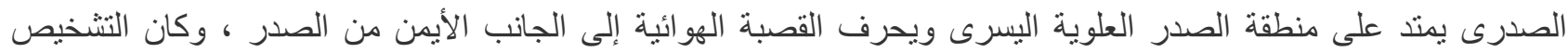

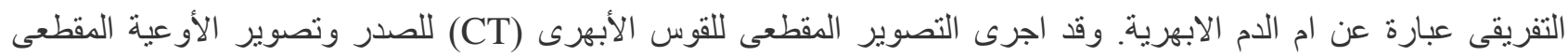

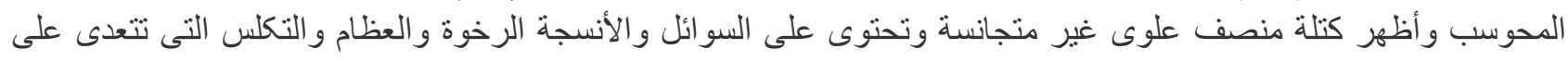
الثريان الرئوى الأيمن وتضغط وتحرف القصبة الهو ائية إلى اليمين. نم إجراء الإز الة الجراحية الكاملة من خلال عملية فتح 


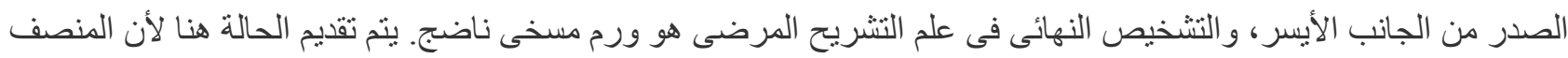

$$
\begin{aligned}
& \text { الصدرى هو موقع نادر للورم المسخى ولم يتم الإبلاغ عن المنصف العلوى كموقع للورم المسخى عالميا من مر اجعة المقالات. } \\
& \text { الكلمات المفتاحية : ورم الخلايـا الجرثومية ، الورم المسخى ، المنصف الصدرى ، ورم المنصف الصدرى العلوى المسخى . }
\end{aligned}
$$

\section{INTRODUCTION}

T he term "teratoma" derives it's origin from the Greek words "terato" and "oncoma" meaning "monster" and "swelling," respectively. Their unpredictable behavior, obscure origin and bizarre microscopic appearance, make them interesting ${ }^{1}$. Primary mediastinal tumors are rare representing $3 \%$ of all tumors within the chest, benign teratomas form only $10 \%$ of them ${ }^{2}$. The anterior mediastinum being the most common site for these tetratomas ${ }^{3}$. After complete surgical excision benign cystic teratomas have excellent prognosis.

\section{Case Report}

A 39 years old male patient presented with progressive exertional dyspnea and orthopnea with frequent attacks of cough for 3 years duration and feeling of pulsatile mass in left upper parasternal area in the last 4 months. Chest x-ray showed superior mediastinal shadow projecting to left upper chest zone and deviating the trachea to the right side of the chest, differential diagnosis was aneurysm of aortic arch and lymphoma. Computed tomography (CT) scan of chest and CT angiography (Fig.1) done and revealed a superior mediastinal cystic mass of heterogeneous opacity containing fluid, soft tissue, bones and calcification encroaching the right pulmonary artery and compressing and deviating the trachea to the right.

Complete surgical removal done through a left thoracotomy. Intraoperatively there was a mass 13 $\mathrm{cm} \times 9 \mathrm{~cm} \times 7.5 \mathrm{~cm}$ present in the superior mediastinum protruding to left hemithorax (Fig.2). The mass was encroaching on great vessels, and severely adherent to pericardium, lung, and chest wall. Complete surgical resection of the mass was done including pieces of pericardium and mediastinal pleura. Patient post operatively developed hoarsiness of voice due to left recurrent laryngeal nerve injury.

Grossly multiple fragments of soft tissue with hair and sebaceous material, bone and cartilage (Fig. 3). Microscopical examination revealed a cyst wall with marked hyaline degenerative changes and calcification, filled with hair, sebum, mature cartilage, respiratory epithelium with mucus secreting glands (Fig. 4). Histopathology reported was benign mature cystic teratoma. The case is being presented here because mediastinum is an uncommon site for teratoma and superior mediastinum is not being reported as a site for teratoma in our region.

\section{DISCUSSION}

Teratomas are tumors with either benign or malignant behavior. They may contain tissues of germ layers either mesodermal or endodermal or ectodermal or mixed elements ${ }^{4}$. Mediastinal teratomas are an extragonadal germ cell tumor, derived from pluripotent cell with the multidirectional potential of differentiation into different types of cell ${ }^{1}$. Furtherly teratomas are classified into mature (cystic or solid) teratomas, immature teratomas, and monodermal (highly specialized) teratomas ${ }^{5}$. This reported case was a case of mature cystic teratoma.

The incidence of teratoma is about 1 per 4,000 live births. The various sites in decreasing order of the frequency of occurrence are as follows: Sacrococcygeal $40 \%$, ovary $25 \%$, other sites including neck and mediastinum $18 \%$, testis $12 \%$ $\&$ brain $5 \%{ }^{1}$. Men and women are equally affected by teratoma with an age ranging from 1 - 73 years, the average age at presentation is 28 years ${ }^{6}$. This case is a superior mediastinal mature cystic teratoma in a 39 years old male.

Most cases of mediastinal mature teratoma are asymptomatic and found incidentally. When symptoms are present, it is due to the compression of adjacent structures. These include cough, dyspnea, chest pain, and respiratory distress. Occasionllyb the teratoma can erode and rupture into the pleural space, pericardium or tracheobronchial tree causing hemoptysis and trichoptysis which is pathognomonic for teratoma ${ }^{7}$. For the case being discussed, the patient had a history of progressive exertional dyspnea and orthopnea with frequent attacks of cough for 3 years duration and feeling of pulsatile mass in left upper parasternal area in the last 4 months.

The imaging technique of choice for evaluation of an abnormal mediastinum is chest CT scan. It shows the site and extension of the mass in relation to the surrounding structures and to detect the vascularity of the mass. The typical appearance is a sharply demarcated, lobulated, heterogeneous mass and the intrinsic components of the mass, including fat, bone, soft tissue, areas 
of cystic calcifications, and fluid which is pathognomonic for diagnosing teratoma ${ }^{8}$. In this case, superior mediastinal mass was reported on CT scan that was suggestive of mediastinal tumor mostly teratoma.

The treatment of choice for mediastinal teratoma is complete surgical resection. It helps in confirming the diagnosis and ensuring a long-term cure rate with little chance of recurrence. Median sternotomy is the most commonly used method because of the excellent exposure. When it affects the hemithorax, then lateral thoracotomy is the approach of choice ${ }^{6}$. In this case complete surgical excision was done through left thoracotomy.

Mediastinal teratoma is usually not fatal by itself but the complications of major surgical procedures (such as pneumonectomy) or bleeding from major vessels, can cause death ${ }^{9}$. In this case, complete surgical excision was done and the patient post operatively developed hoarseness of voice due to left recurrent laryngeal nerve injury which was reported as a complication in extensive left mediastinal dissection.

Malignant transformation of mature cystic teratomas (MCTs) is rare and occur in $0.17 \%-2 \%$ of them. Squamous cell carcinoma is the most common type of malignant transformation, and there are few reports about multiple malignancies developing in a single MCT ${ }^{10}$. Extensive tissue sampling was done for this case to exclude any immature or any malignant component but it did not show any evidence of malignancy.

Though benign, it is important to diagnose mediastinal teratomas as they can cause symptoms resulting from compression of adjacent structures such as threatening respiratory distress. Mature teratomas are benign tumors and have an excellent prognosis after complete resection, and so there is no role for adjuvant radiotherapy or chemotherapy in their management.

\section{CONCLUSION}

Superior mediastinal teratoma has been rarely reported previously, and this is the first reported case in our locality, complete excision of the tumor is possible and curative. The patient is followed up for 6 months and he is doing well apart of mild hoarseness of voice with no evidence of recurrence.
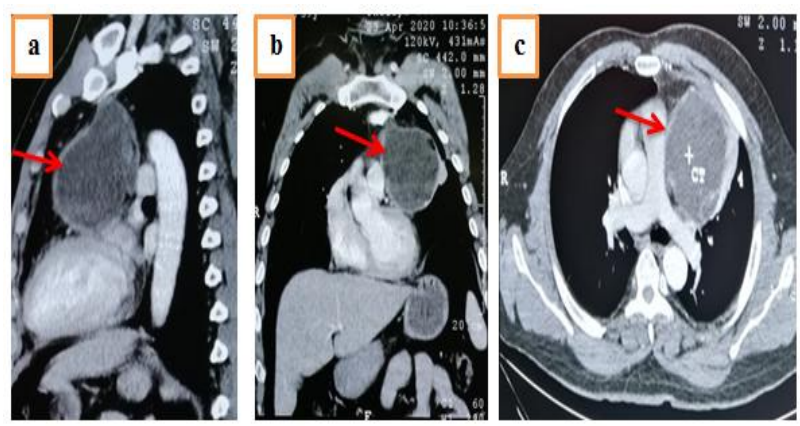

Fig. 1: CT scan of chest showing superior mediastinal cystic mass of heterogeneous opacity

(arrow) containing fluid, soft tissue, bones and calcification encroaching the right pulmonary artery and compressing and deviating the trachea to the right. (a. Lateral view , b. anterior view \& c. axial section).
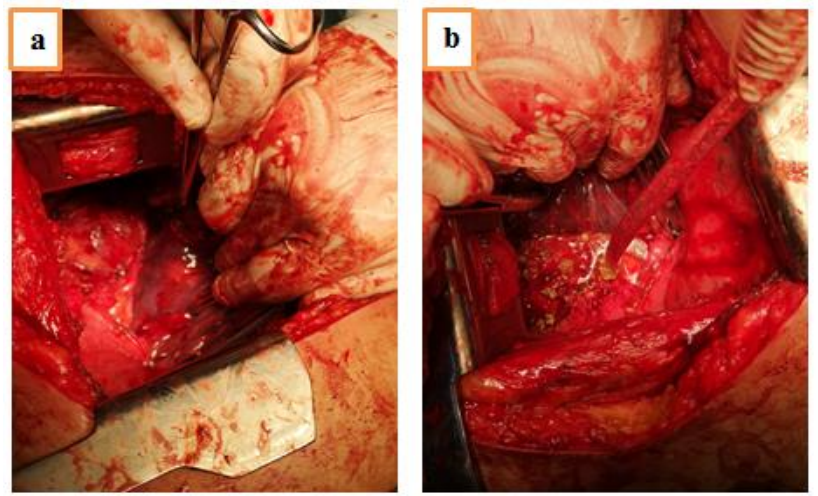

Fig. 2: (a \&b) Left posterolateral thoracotomy for removal of superior mediastinal teratoma
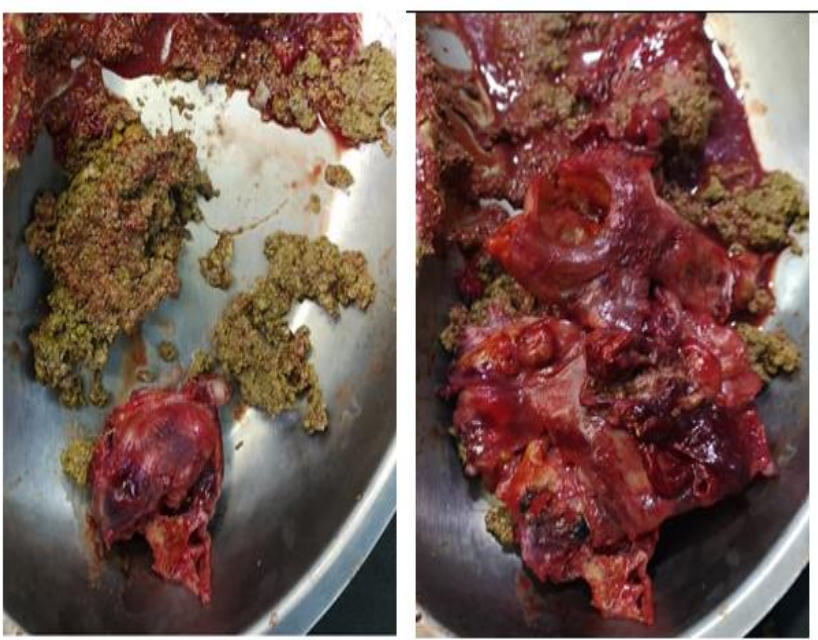

Fig. 3: Superior mediastinal teratoma. The gross appearance shows red \& gray tissue with cyst content. 

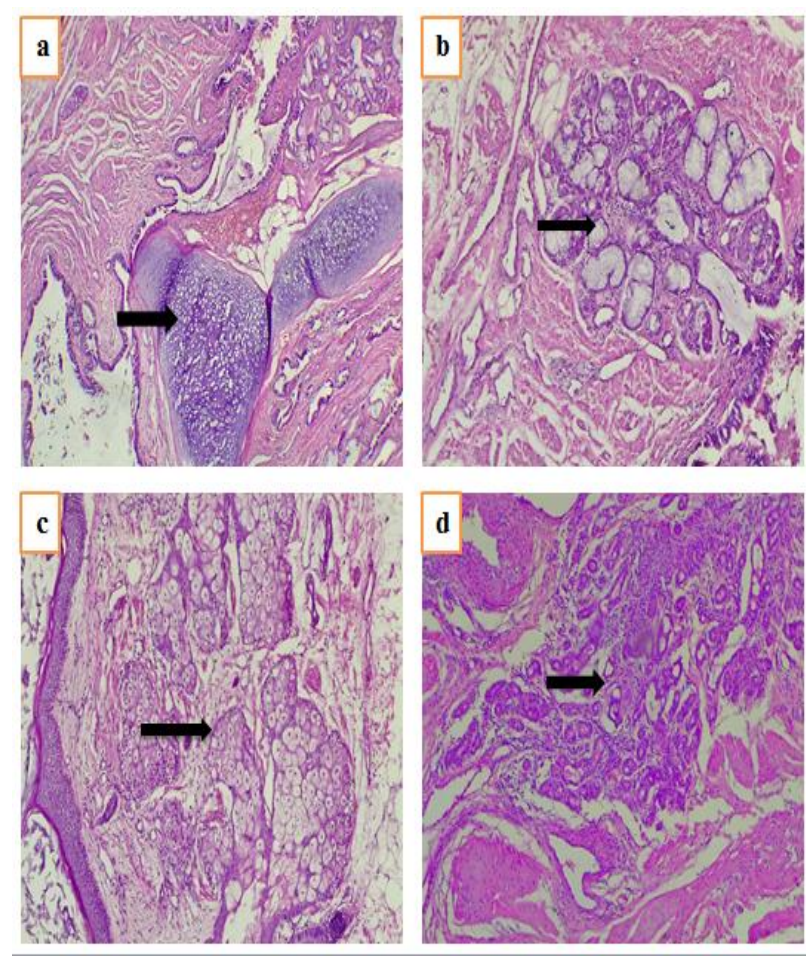

Fig. 4: Superior mediastinal mature teratoma.

Showing; a- cartilage, b- respiratory mucosa, cskin and sebaceous glands, d-glands and fibrocollagenous tissue. (H \& E stain 100X)

\section{REFERENCES}

1.Dhond AP, Agrawal SO, Sirmukaddam SV, Srinath S, Roplekar P, Desai PR. Mediastinal teratoma: A case report with review of literature. J Sci Soc 2016;43:57-9.

2. Dalal UR, Dalal AK, Kartik A, Saini V, Anand L . Clinicopathological profile of primary mediastinal masses: our experience. J Surg Anesth 2020;4:1.

3.Carter BW, Marom EM, Detterbeck FC. Approaching the patient with an anterior mediastinal mass: a guide for clinicians. J Thorac Oncol. 2014;9:102-9.

4. Hassan AU, Khanday S, Ahad F , Rasool Z, Rasool Z. Teratomas: the unique masses: embryological, histopathological and clinical perspective. Sch. J. App. Med. Sci. 2014; 2(2A):551-3.

5. Tejani AS, He L, Zheng W, Vijay K. Concurrent, bilateral presentation of immature and mature ovarian teratomas with refractory hyponatremia: A case report. J Clin Imaging Sci. 2020; 10: 23.

6. Yalagachin GH. Anterior mediastinal teratoma- a case report with review of literature. Indian $\mathrm{J}$ Surg 2013;75:182-4.
7.Badar F, Yasmeen S, Afroz N, Khan N, Azfar SF. Benign mediastinal teratoma with intrapulmonary and bronchial rupture presenting with recurrent hemoptysis. Iran $\mathrm{J}$ Radiol 2013;10:86-9.

8. Dalal U, Jora MS, Dalal AK, Attri AK, Singal R, Gupta S. Primary germ cell tumor of the mediastinum - presenting as a huge mass. Int $\mathrm{J}$ Prev Med 2014;5:230-2.

9. Agarwal G, Kar DK. Teratoma of the anterior mediastinum presenting as a cystic neck mass: A case report. J Med Case Rep 2008;2:23.

10. Cagino K, Levitan D, Schatz-Siemers N, Zarnegar R, Chapman-Davis E, Holcomb K, et al. Multiple malignant transformations of an ovarian mature cystic teratoma. ecancer 2020; 14:1009. 